\title{
Key pathways and genes controlling the development and progression of clear cell renal cell carcinoma (ccRCC) based on gene set enrichment analysis
}

\author{
Haipeng Huang $\cdot$ Yanyan Tang $\cdot$ Wenwu He $\cdot$ \\ Qi Huang $\cdot$ Jianing Zhong $\cdot$ Zhanbin Yang
}

Received: 15 April 2013/Accepted: 1 July 2013/Published online: 14 August 2013

(C) The Author(s) 2013. This article is published with open access at Springerlink.com

\begin{abstract}
Background Clear-cell renal cell carcinoma (ccRCC) is one of the most common types of kidney cancer in adults; however, its causes are not completely understood. The study was designed to filter the key pathways and genes associated with the occurrence or development of ccRCC, acquaint its pathogenesis at gene and pathway level, to provide more theory evidence and targeted therapy for ccRCC.

Methods Gene set enrichment analysis (GSEA) and metaanalysis (Meta) were used to screen the critical pathways and genes which may affect the occurrence and progression of ccRCC on the transcription level. Corresponding pathways of significant genes were obtained with the online website DAVID (http://david.abcc.ncifcrf.gov/).

Results Thirty seven consistent pathways and key genes in these pathways related to ccRCC were obtained with
\end{abstract}

Haipeng Huang, Yanyan Tang and Wenwu He have contributed equally to this work.

H. Huang $\cdot$ Z. Yang $(\bowtie)$

Department of Urinary Surgery, The First Affiliated Hospital,

Guangxi Medical University, 6th Shuangyong Road,

Nanning 530021, Guangxi, China

e-mail: yangzhanbin@126.com

Y. Tang $\cdot$ Q. Huang

Department of Neurology, First Affiliated Hospital,

Guangxi Medical University, Nanning, Guangxi, China

W. He

Department of Cardiothoracic Surgery, Nanchong Central Hospital, The Second Clinical College of North Sichuan

Medical College, Nanchong, Sichuan, China

J. Zhong

Guilin Medical College, Guilin, Guangxi, China combined GSEA and meta-analysis. These pathways were mainly involved in metabolism, organismal systems, cellular processes and environmental information processing. Conclusion The gene pathways that we identified could provide insight concerning the development of ccRCC. Further studies are needed to determine the biological function for the positive genes.

Keywords Clear-cell renal cell carcinoma (ccRCC) - Gene set enrichment analysis . Meta-analysis · Key pathways

\section{Introduction}

Renal cell carcinoma (RCC) is one of the most common genitourinary malignancies, accounting for about $3 \%$ of all cancers worldwide [1]. Clear cell renal cell carcinoma (ccRCC) is the most common histological type of renal cell carcinoma, also called conventional RCC, which represents $75-80 \%$ of RCC. The male/female ratio is approximately $2: 1$ [2]. Initial treatment is most commonly a radical or partial nephrectomy and remains the mainstay of curative treatment [3]. Where the tumor is confined to the renal parenchyma, the 5-year survival rate is $60-70 \%$, but this is lowered considerably where metastases have spread. It is relatively resistant to radiation therapy and chemotherapy, although some cases respond to immunotherapy.

After the completion of the Human Genome Project, advances in microarray technology led to global gene expression profiling of ccRCC [4-6]. Microarray technology profiles the expression levels of thousands of genes simultaneously, providing a snapshot of transcript levels in the cells/tissues being studied; it is a powerful tool to study ccRCC. All microarray data are available 
from the Gene Expression Omnibus (GEO) public database at NCBI [7]. However, the large amounts of data acquired must be reduced or 'translated' to a smaller set of genes representing meaningful biological differences between control and test systems and validated in an experimental or clinical setting. It is a challenge to analyze such high information from microarray datasets to identify molecular pathways and key genes deregulated in ccRCC. To resolve this conflict, Subramanian describes a method gene set enrichment analysis (GSEA) which has been recognized as a breakthrough for the gene set and functional pathways analysis [8]. GSEA is a method that allows us to search the key genes and pathways associated with the occurrence and development of disease by analyzing diverse experimental datasets. However, the difference of platforms, the sample capacity and the standardization affect the result more or less. Metaanalysis of microarray data can be a better way to solve the problem of poor reproducibility and reliability [9]. In our study, after a standardized microarray preprocessing for all the expression datasets, GSEA and a meta-analysis were used to detect the mixing pathways and key genes which can provide the theoretical basis to the further perception of the biological mechanism of ccRCC.

\section{Materials and methods}

Data collection

We used clear cell renal cell carcinoma as the keywords and set the limit of study type expression profiling by array and a species limit of humans to search GEO (http://www. ncbi.nlm.nih.gov/geo/) for the relevant gene datasets. Search results provided 2,762 identified datasets involved in ccRCC. Studies that met all of the following criteria were included: (1) the data were about genome-wide RNA expression; (2) the complete microarray raw or normalized data were effective; (3) the data provided a comparison of renal tissue between ccRCC patients and normal controls relatively; (4) datasets contained more than three samples; (5) the raw data were expressed as CEL files. Finally, there were three gene expression datasets which met the selection criteria (Table 1).
Gene set enrichment analysis

The category version 2.10.1 package was used to perform with GSEA. General statistical analysis and computing was processed in the $\mathrm{R}$ statistical programming language [10]. The Robust Multichip Averaging (RMA) [11] algorithm in the affy conductor package [12] was used for each affymetrix raw dataset to calculate background-adjusted, normalized and $\log 2$ probe set intensities. The only genes we selected should have been mapped to an explicit KEGG pathway for the purpose of analyzing the GSEA and metaanalysis further [13]. We performed pathway analysis of each dataset independently. The measure of variability was within the interquartile range (IQR) and a cut-off was set up to remove IQR values under 0.5 for all the remaining genes. If one gene was targeted for multiple probe sets, we retained the probe set with the largest variability. Genes in each pathway went through the Student's $t$ test, and each pathway's $p$ value was obtained in the permutation test with 1,000 times. The $p$ value was not more than 0.05 .

\section{Meta-analysis}

To obtain the differentially expressed genes from the remaining genes of each dataset above, meta-analysis was carried out in SAS 9.13. The following formula was applied to calculate chi-square value of each gene [14]:

$X^{2}=-2 \sum_{i=1}^{\mathrm{k}} \log _{\mathrm{e}} P^{\mathrm{i}}$

( $\mathrm{K}$ is the number of the datasets).

To calculate $p$ value of each gene, and retained the genes with $p<0.05$. Significant genes were used to obtain the pathways of the KEGG from DAVID Bioinformatics Resources 6.7 (http://david.abcc.ncifcrf.gov/).

\section{Results}

\section{GSEA analysis}

According to the inclusion criteria, we obtained three datasets in the end. Tissues used to extract the total RNA were matched pairs from clear cell renal cell carcinoma and

Table 1 Characteristics of datasets selected in the studies

\begin{tabular}{lllllllrr}
\hline GEO accession & Contributor & Years & Chip & Experimental design & Probs & Source & Disease & Normal \\
\hline GSE781 & Lenburg ME & 2003 & HG-U133A & Paired, tissues & 22,283 & Homo sapiens & 7 \\
GSE6344 & Gumz ML & 2007 & HG-U133A & Paired, tissues & 22,283 & Homo sapiens & 10 & 10 \\
GSE36895 & Peña-Llopis S & 2012 & HG-U133_Plus_2 & Paired, tissues & 54,675 & Homo sapiens & 23 & 23
\end{tabular}

Paired = compare clear cell renal carcinomas to normal controls from the same patients with clear cell renal carcinoma 
normal tissue adjacent to renal cell carcinoma. The fuhrman grade of ccRCC was no more than three. Due to the samples used, genomic profiling were matched pairs. It reduced the influence of multiple factors on GSEA and Meta-analysis, ensuring the reliability of the obtained conclusion.

The three inclusion datasets contained $40 \mathrm{ccRCC}$ cases and 40 controls. GSEA method was used separately on each dataset to find the significantly changed genes and the significant co-pathways. After GSEA analysis, 8,506 significantly changed genes were screened out from the three gene expression microarray datasets. Overlap existed in the up-regulated and down-regulated pathways. There were fourteen mixing pathways including 206 up-regulated and 253 down-regulated pathways from three datasets. Detailed information about the analysis results is shown in Table 2.

\section{Meta-analysis}

To further identify the results above, meta-analysis was used to detect differentially expressed genes between two experimental groups. We got the $p$ value for each gene based on unpaired $t$ test. A total of 1,150 significant genes were detected $(p<0.05)$. Furthermore, the Database for Annotation, Visualization and Integrated Discovery (DAVID) (http://david.abcc.ncifcrf.gov/) was utilized for the annotation of these genes. We imported the official gene symbols of 1,150 genes into the gene functional classification tool of DAVID. In order to identify biologically relevant molecular networks of these genes, KEGG (http://www.genome.jp/kegg/), a distinct pathway analysis tools of bioinformatics endowed with comprehensive knowledgebase was used. There were 1,038 genes identified by KEGG. In total, 48 KEGG pathways were detected. More details were shown in Table 3.

The results of GSEA and meta-analysis

To search the intersection pathways, a comparative analysis was made subsequently between the significant common pathways of GSEA and meta-analysis. At last, 37 consistent pathways and significant genes $(p<0.05)$ in these pathways were obtained. These pathways mainly concerned metabolism, organismal systems, cellular processes, environmental information processing, and human diseases. The details are shown in Table 4.

\section{Discussion}

Clear cell renal cell carcinoma is one of the most common types of kidney cancer in adult; however, its causes are not completely understood. The selection of differentially expressed genes and consistent pathways helps us to explore their underlying molecular mechanisms, thereby providing insights into biological function. Single genemarker-based approaches can fail to detect transcriptional programs that are distributed across an entire network of genes are yet subtle at the level of individual gene [15]. Genome-wide microarrays can locate gene families and pathways which show a consistent alteration in a disease state. Pathway analysis is a valid method to reduce a major deviation and can obtain interesting common genes and pathways by mixing differently expressed genes from different datasets.

Some studies have been published. The study of Tun et al. [16] used gene expression profiling of early-stage ccRCC combined with a comprehensive bioinformatics analyses to reveal the significant pathway and transcription factors which take effect in the development of ccRCC. Meanwhile, Maruschke et al. [17] used microarray expression analysis to determine 16 gene sets that distinguish expression profiles from grade 1 and grade 3 tumor tissues based on MSigDB data bank analysis. The two studies above were single dataset analysis. However, multimicroarray dataset analysis for the development of ccRCC was rare. This study uses three datasets based on a novel GSEA carried out by KEGG dataset and meta-analysis approach to identify the common significant genes and genetic pathways with $p<0.05$ associated ccRCC. And our findings suggest that most genes and pathways involved in ccRCC are the same according to their functional classification. In this study, we discussed several differentially expressed pathways and genes among crossing pathways which suggest the role of these pathways and genes in ccRCC based on their functional classification.

Metabolism pathways

The metabolism pathways in our study were predominantly focused on carbohydrate metabolism, lipid metabolism, energy metabolism, amino acid metabolism, metabolism of other amino acids, metabolism of cofactors and vitamins.
Table 2 Summary of each dataset used gene set enrichment analysis (GSEA)

\begin{tabular}{lccllc}
\hline Studies & $\begin{array}{l}\text { Number of } \\
\text { patients }\end{array}$ & $\begin{array}{l}\text { Number of } \\
\text { controls }\end{array}$ & $\begin{array}{l}\text { Number of significantly } \\
\text { changed genes after GSEA }\end{array}$ & $\begin{array}{l}\text { Up-regulated } \\
\text { pathways }\end{array}$ & $\begin{array}{l}\text { Down-regulated } \\
\text { pathways }\end{array}$ \\
\hline GSE781 & 7 & 7 & 2,689 & 73 & 57 \\
GSE6344 & 10 & 10 & 2,644 & 68 & 96 \\
GSE36895 & 23 & 23 & 3,173 & 65 & 100 \\
\hline
\end{tabular}


Table 3 Common significant pathways were obtained from 3 clear cell renal carcinoma tissue datasets by meta-analysis

\begin{tabular}{|c|c|c|c|c|}
\hline $\begin{array}{l}\text { Pathway } \\
\text { entry }\end{array}$ & Pathway names & $p$ value & $\begin{array}{l}\text { Number of } \\
\text { genes } \\
\text { expressed in } \\
\text { the pathways }\end{array}$ & $\begin{array}{l}\text { Up- or } \\
\text { down- } \\
\text { regulated } \\
\text { pathways }\end{array}$ \\
\hline map00280 & $\begin{array}{l}\text { Valine, leucine } \\
\text { and isoleucine } \\
\text { degradation }\end{array}$ & $8.79 \mathrm{E}-14$ & 33 & Up \\
\hline map00020 & $\begin{array}{l}\text { Citrate cycle } \\
\text { (TCA cycle) }\end{array}$ & $1.55 \mathrm{E}-10$ & 24 & Up \\
\hline map00010 & $\begin{array}{l}\text { Glycolysis/ } \\
\text { gluconeogenesis }\end{array}$ & $1.41 \mathrm{E}-08$ & 33 & $\mathrm{Up}$ \\
\hline map00640 & $\begin{array}{l}\text { Propanoate } \\
\text { metabolism }\end{array}$ & $3.35 \mathrm{E}-08$ & 22 & $\mathrm{Up}$ \\
\hline map00071 & $\begin{array}{l}\text { Fatty acid } \\
\text { metabolism }\end{array}$ & $2.58 \mathrm{E}-07$ & 24 & Up \\
\hline map00620 & $\begin{array}{l}\text { Pyruvate } \\
\text { metabolism }\end{array}$ & $1.34 \mathrm{E}-06$ & 23 & Up \\
\hline map00650 & $\begin{array}{l}\text { Butanoate } \\
\text { metabolism }\end{array}$ & $5.21 \mathrm{E}-06$ & 20 & Up \\
\hline map00330 & $\begin{array}{l}\text { Arginine and } \\
\text { proline } \\
\text { metabolism }\end{array}$ & $1.16 \mathrm{E}-04$ & 24 & Up \\
\hline map00190 & $\begin{array}{l}\text { Oxidative } \\
\text { phosphorylation }\end{array}$ & $4.13 \mathrm{E}-04$ & 44 & Up \\
\hline map00260 & $\begin{array}{l}\text { Glycine, serine } \\
\text { and threonine } \\
\text { metabolism }\end{array}$ & $4.36 \mathrm{E}-04$ & 16 & Up \\
\hline map05012 & $\begin{array}{l}\text { Parkinson's } \\
\text { disease }\end{array}$ & $5.80 \mathrm{E}-04$ & 43 & Up \\
\hline map04514 & $\begin{array}{l}\text { Cell adhesion } \\
\text { molecules } \\
\text { (CAMs) }\end{array}$ & $5.95 \mathrm{E}-04$ & 44 & Down \\
\hline map03320 & $\begin{array}{l}\text { PPAR signaling } \\
\text { pathway }\end{array}$ & $6.52 \mathrm{E}-04$ & 27 & Up \\
\hline map05416 & Viral myocarditis & 0.00107 & 27 & Down \\
\hline map00380 & $\begin{array}{l}\text { Tryptophan } \\
\text { metabolism }\end{array}$ & 0.00119 & 18 & Up \\
\hline map04142 & Lysosome & 0.00129 & 39 & Up \\
\hline map00410 & $\begin{array}{l}\text { beta-Alanine } \\
\text { metabolism }\end{array}$ & 0.00183 & 12 & Up \\
\hline map00100 & $\begin{array}{l}\text { Steroid } \\
\text { biosynthesis }\end{array}$ & 0.00292 & 10 & Up \\
\hline map04610 & $\begin{array}{l}\text { Complement and } \\
\text { coagulation } \\
\text { cascades }\end{array}$ & 0.00363 & 25 & Up \\
\hline map00051 & $\begin{array}{l}\text { Fructose and } \\
\text { mannose } \\
\text { metabolism }\end{array}$ & 0.00451 & 15 & Down \\
\hline map04612 & $\begin{array}{l}\text { Antigen } \\
\text { processing and } \\
\text { presentation }\end{array}$ & 0.00605 & 28 & Down \\
\hline map05219 & Bladder cancer & 0.00611 & 17 & Down \\
\hline map05212 & Pancreatic cancer & 0.00669 & 25 & Down \\
\hline map00670 & $\begin{array}{l}\text { One carbon pool } \\
\text { by folate }\end{array}$ & 0.00782 & 9 & $\mathrm{Up}$ \\
\hline map05330 & $\begin{array}{l}\text { Allograft } \\
\text { rejection }\end{array}$ & 0.00819 & 15 & Down \\
\hline
\end{tabular}

Table 3 continued

\begin{tabular}{|c|c|c|c|c|}
\hline $\begin{array}{l}\text { Pathway } \\
\text { entry }\end{array}$ & Pathway names & $p$ value & $\begin{array}{l}\text { Number of } \\
\text { genes } \\
\text { expressed in } \\
\text { the pathways }\end{array}$ & $\begin{array}{l}\text { Up- or } \\
\text { down- } \\
\text { regulated } \\
\text { pathways }\end{array}$ \\
\hline map00310 & $\begin{array}{l}\text { Lysine } \\
\text { degradation }\end{array}$ & 0.01017 & 17 & Up \\
\hline map05110 & $\begin{array}{l}\text { Vibrio cholerae } \\
\text { infection }\end{array}$ & 0.01223 & 20 & Up \\
\hline map00903 & $\begin{array}{l}\text { Limonene and } \\
\text { pinene } \\
\text { degradation }\end{array}$ & 0.01281 & 8 & Up \\
\hline map05130 & $\begin{array}{l}\text { Pathogenic } \\
\text { Escherichia coli } \\
\text { infection }\end{array}$ & 0.01493 & 20 & Down \\
\hline map04940 & $\begin{array}{l}\text { Type I diabetes } \\
\text { mellitus }\end{array}$ & 0.01510 & 16 & Down \\
\hline map05010 & $\begin{array}{l}\text { Alzheimer's } \\
\text { disease }\end{array}$ & 0.01525 & 46 & Up \\
\hline map04540 & Gap junction & 0.01631 & 28 & Down \\
\hline map00630 & $\begin{array}{l}\text { Glyoxylate and } \\
\text { dicarboxylate } \\
\text { metabolism }\end{array}$ & 0.01987 & 8 & Up \\
\hline map00072 & $\begin{array}{l}\text { Synthesis and } \\
\text { degradation of } \\
\text { ketone bodies }\end{array}$ & 0.02115 & 6 & Down \\
\hline map05214 & Glioma & 0.02205 & 21 & Down \\
\hline map05222 & $\begin{array}{l}\text { Small cell lung } \\
\text { cancer }\end{array}$ & 0.02571 & 26 & Down \\
\hline map04512 & $\begin{array}{l}\text { ECM-receptor } \\
\text { interaction }\end{array}$ & 0.02571 & 26 & Down \\
\hline map05120 & $\begin{array}{l}\text { Epithelial cell } \\
\text { signaling in } \\
\text { helicobacter } \\
\text { pylori infection }\end{array}$ & 0.02621 & 22 & Up \\
\hline map04510 & Focal adhesion & 0.03278 & 53 & Down \\
\hline map00250 & $\begin{array}{l}\text { Alanine, aspartate } \\
\text { and glutamate } \\
\text { metabolism }\end{array}$ & 0.03679 & 12 & Up \\
\hline map04666 & $\begin{array}{l}\text { Fc gamma } \\
\text { R-mediated } \\
\text { phagocytosis }\end{array}$ & 0.03719 & 28 & Down \\
\hline map04360 & Axon guidance & 0.03811 & 36 & Down \\
\hline map04012 & $\begin{array}{l}\text { ErbB signaling } \\
\text { pathway }\end{array}$ & 0.03873 & 26 & $\mathrm{Up}$ \\
\hline map05332 & $\begin{array}{l}\text { Graft-versus-host } \\
\text { disease }\end{array}$ & 0.04031 & 14 & Down \\
\hline map05200 & $\begin{array}{l}\text { Pathways in } \\
\text { cancer }\end{array}$ & 0.06820 & 79 & Down \\
\hline map00270 & $\begin{array}{c}\text { Cysteine and } \\
\text { methionine } \\
\text { metabolism }\end{array}$ & 0.06916 & 12 & Up \\
\hline map05320 & $\begin{array}{l}\text { Autoimmune } \\
\text { thyroid disease }\end{array}$ & 0.08014 & 16 & Down \\
\hline map05322 & $\begin{array}{l}\text { Systemic lupus } \\
\text { erythematosus }\end{array}$ & 0.09307 & 27 & Down \\
\hline
\end{tabular}




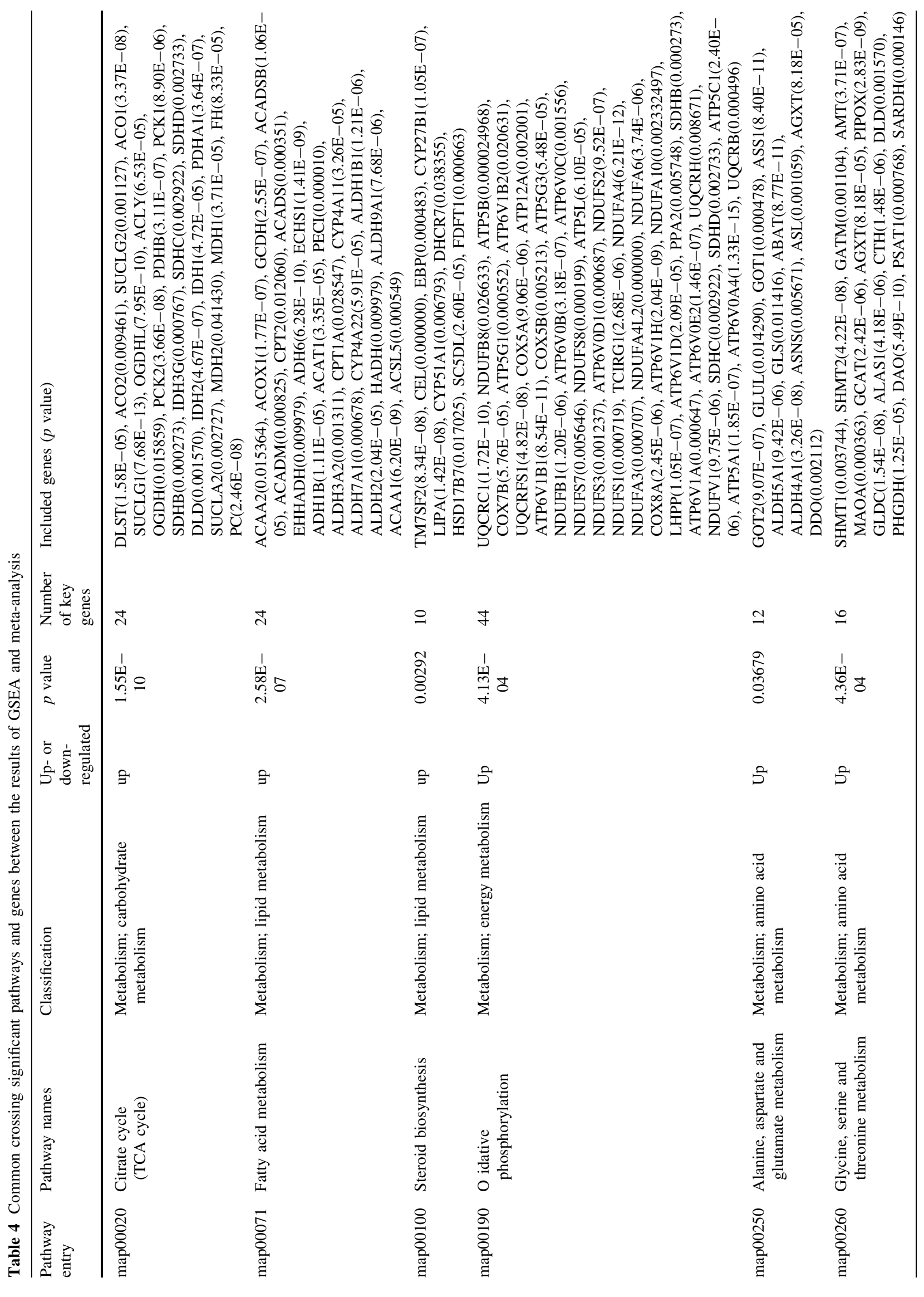




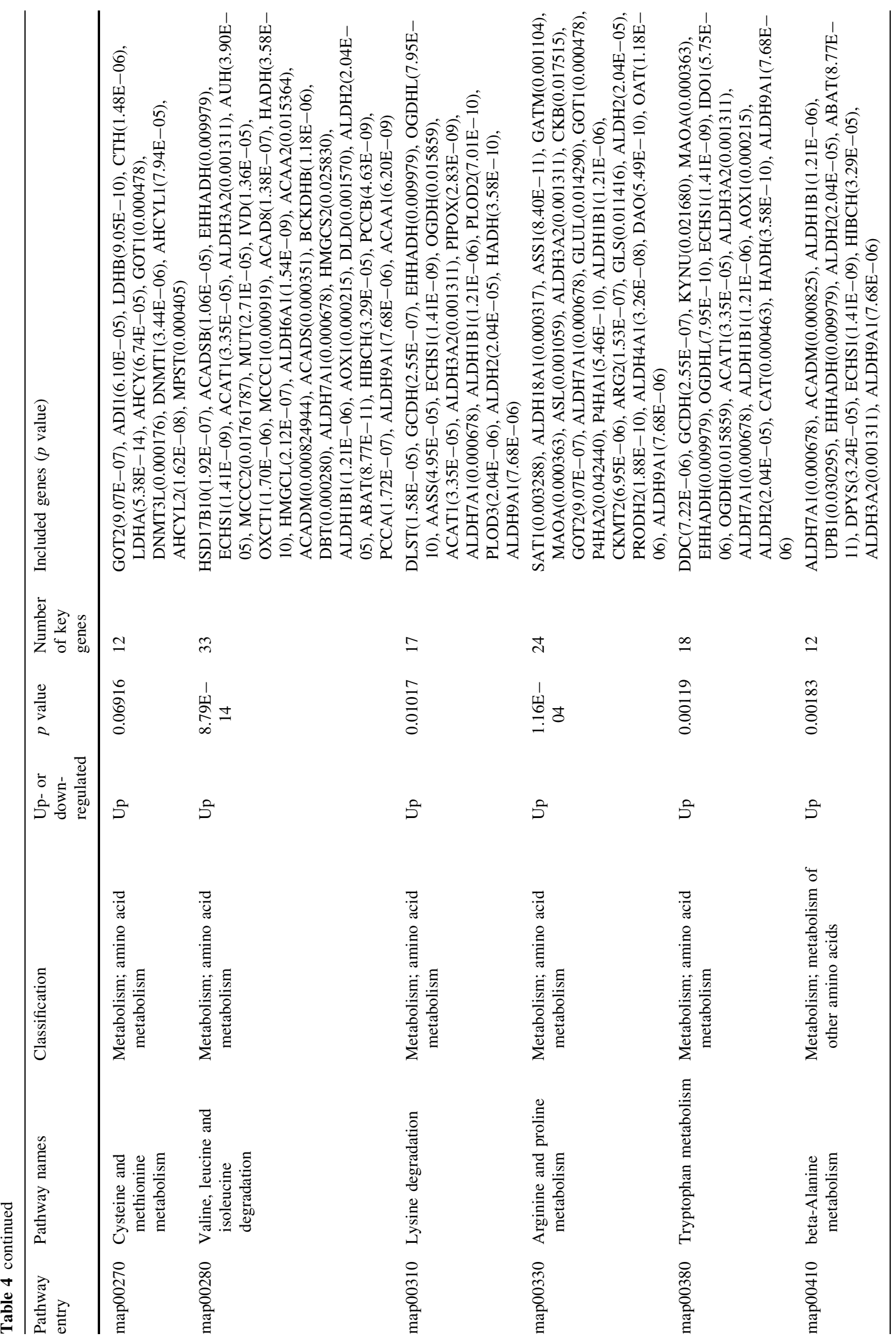




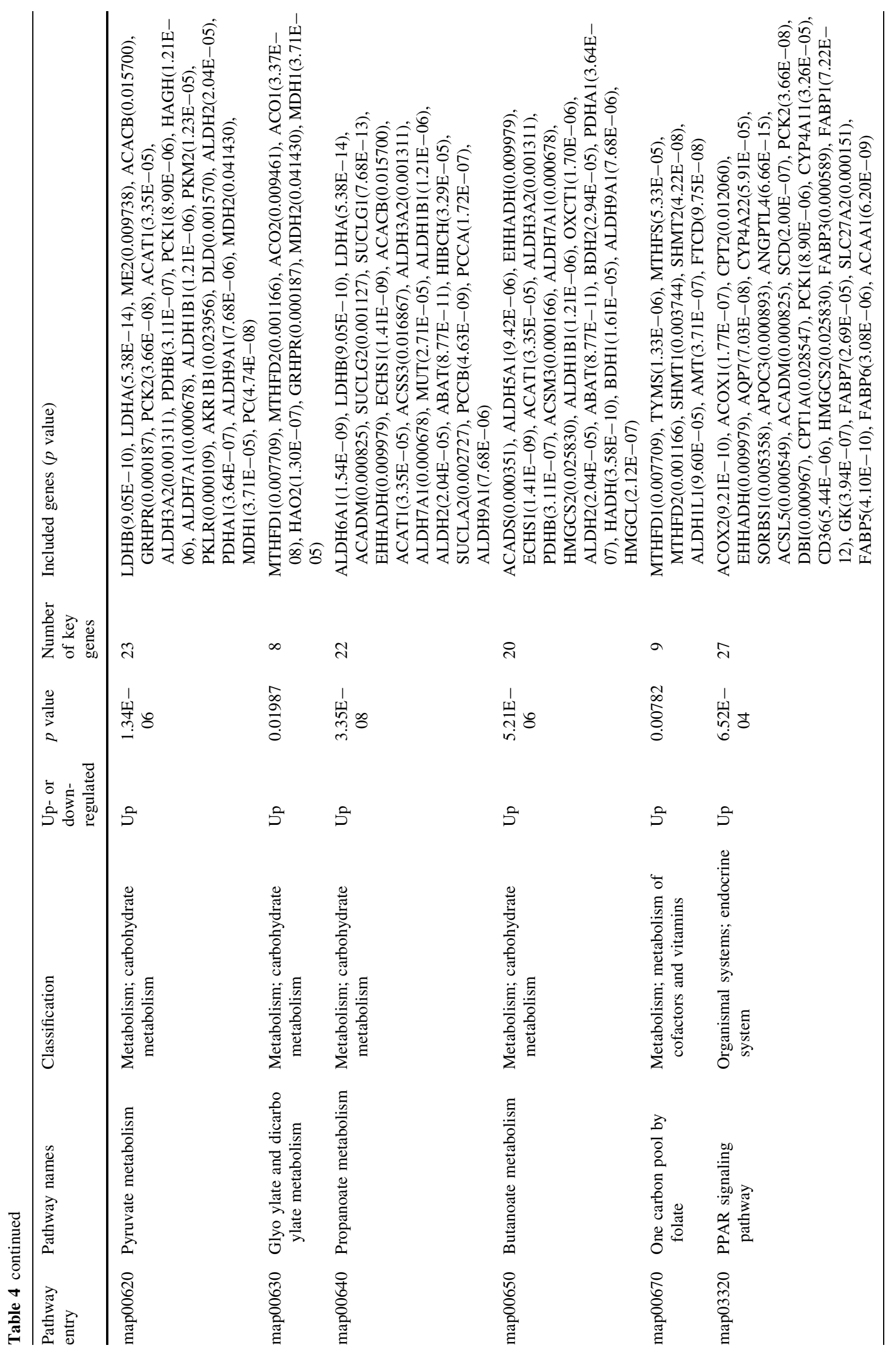




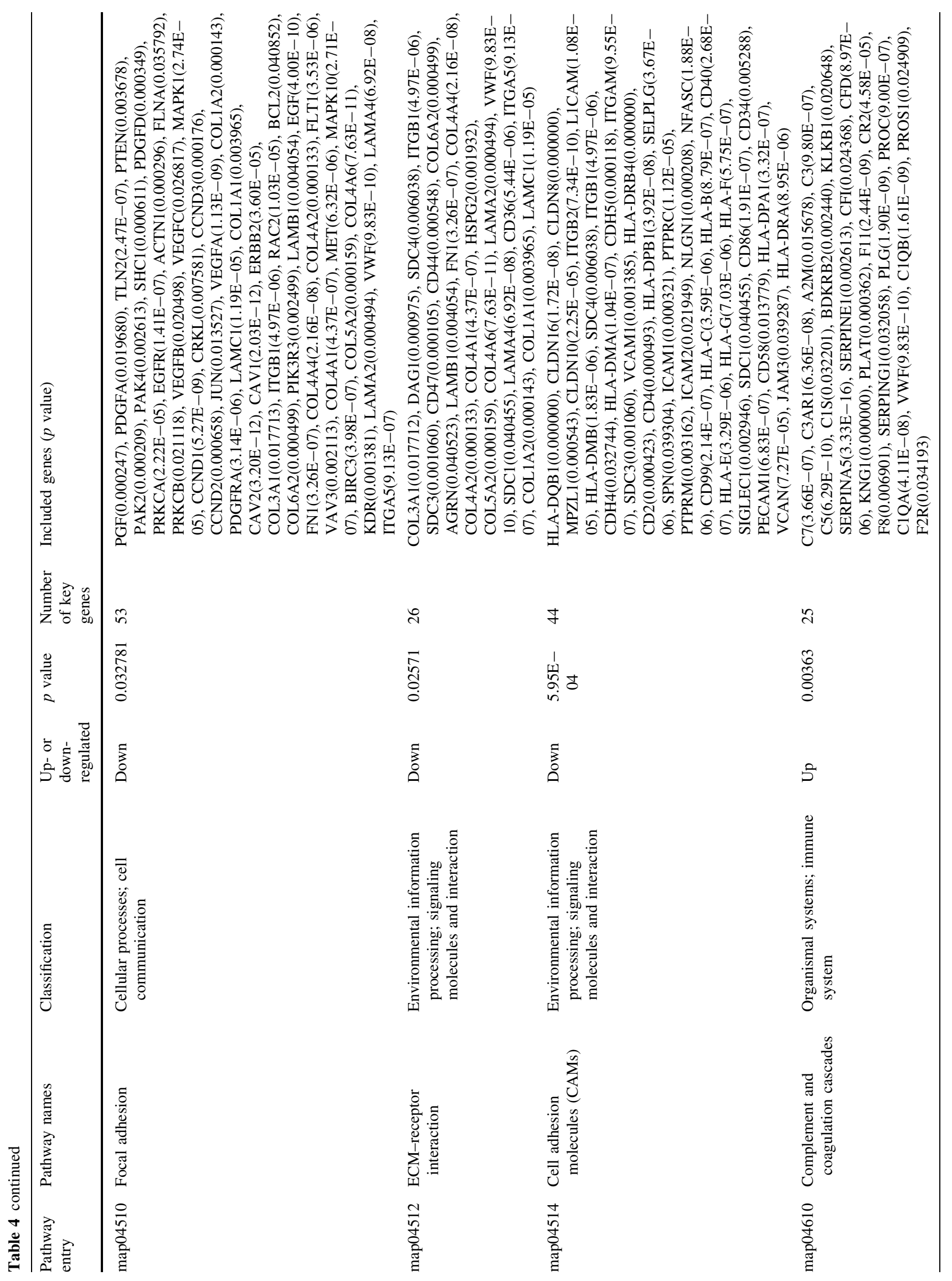




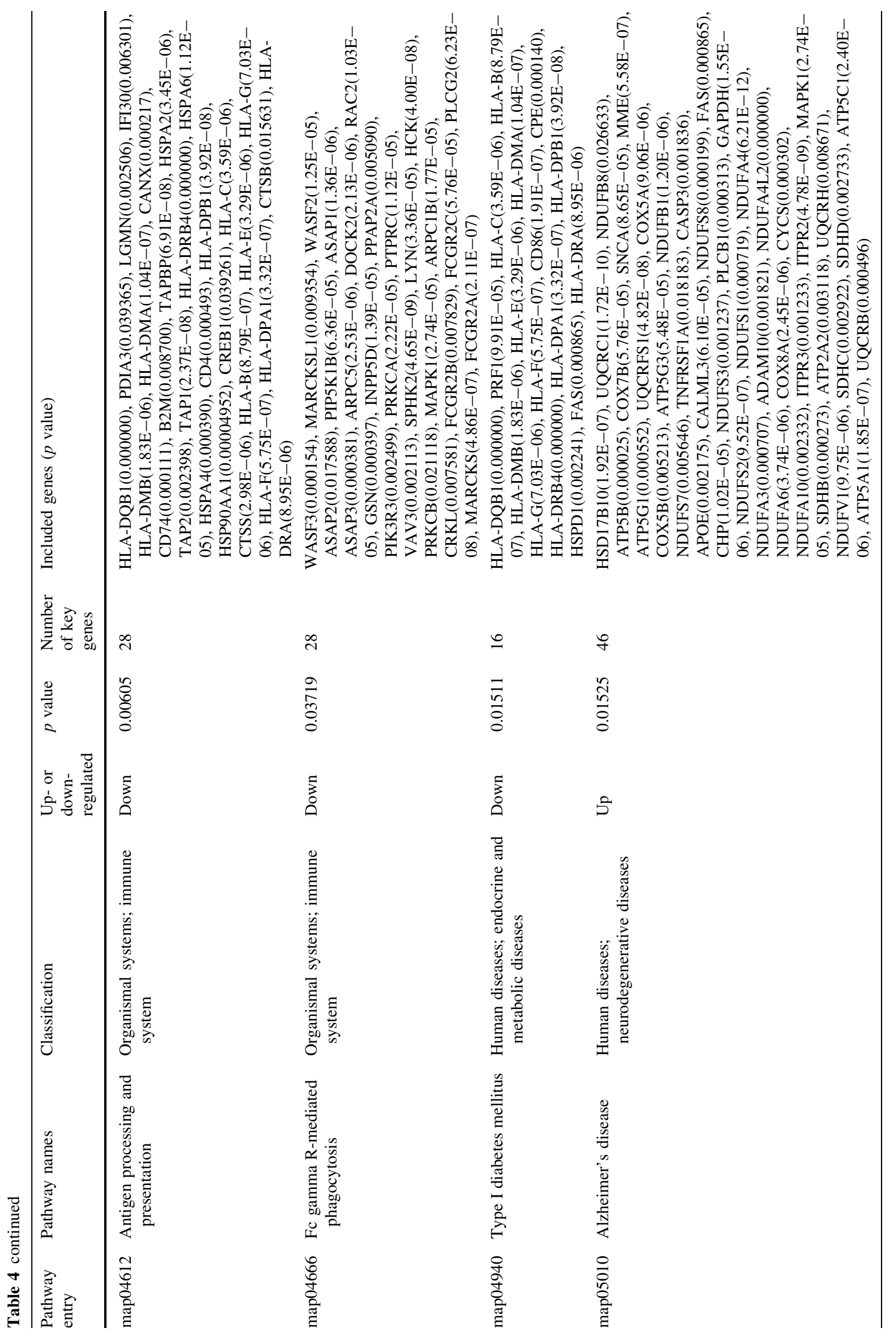




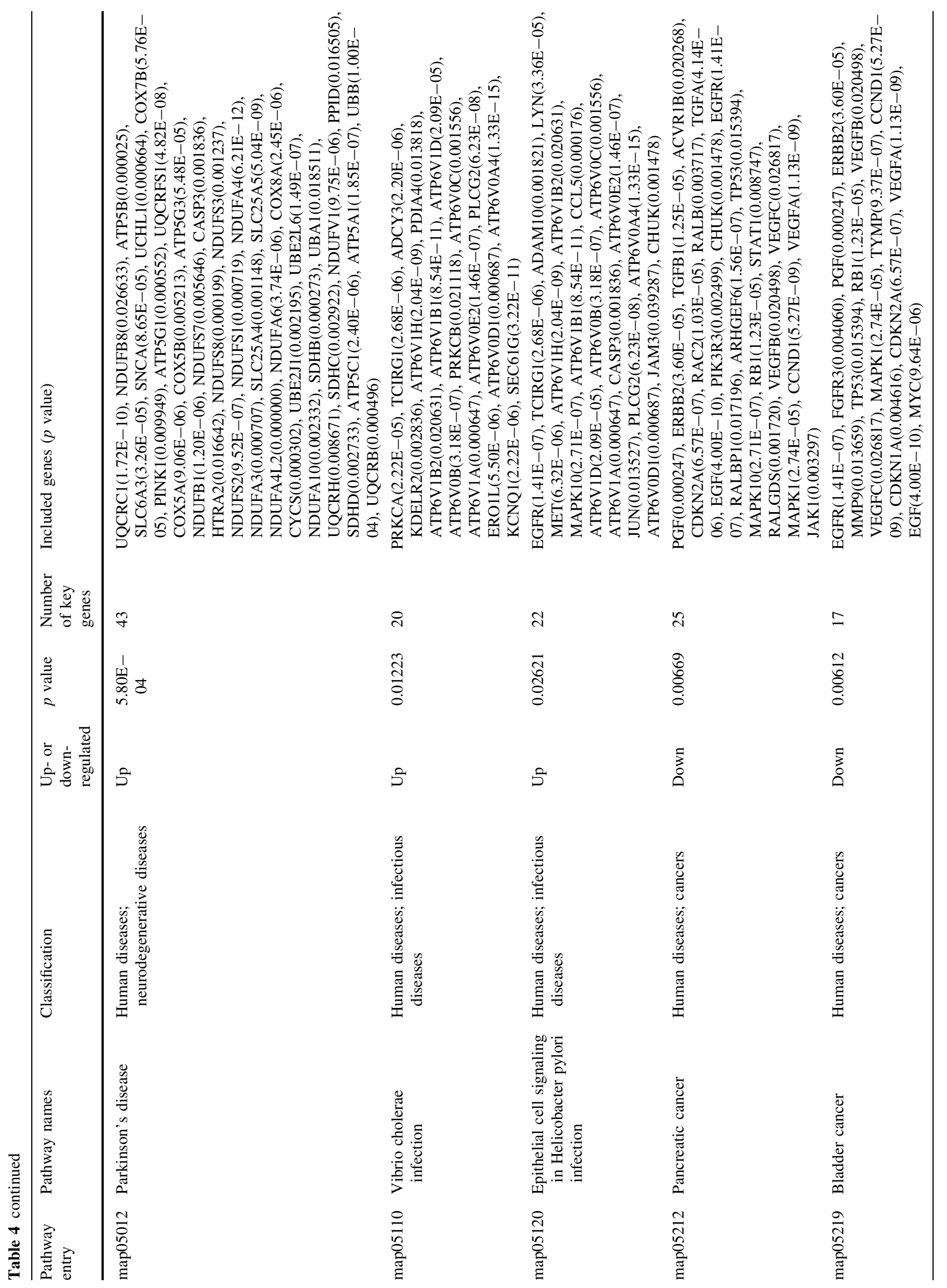




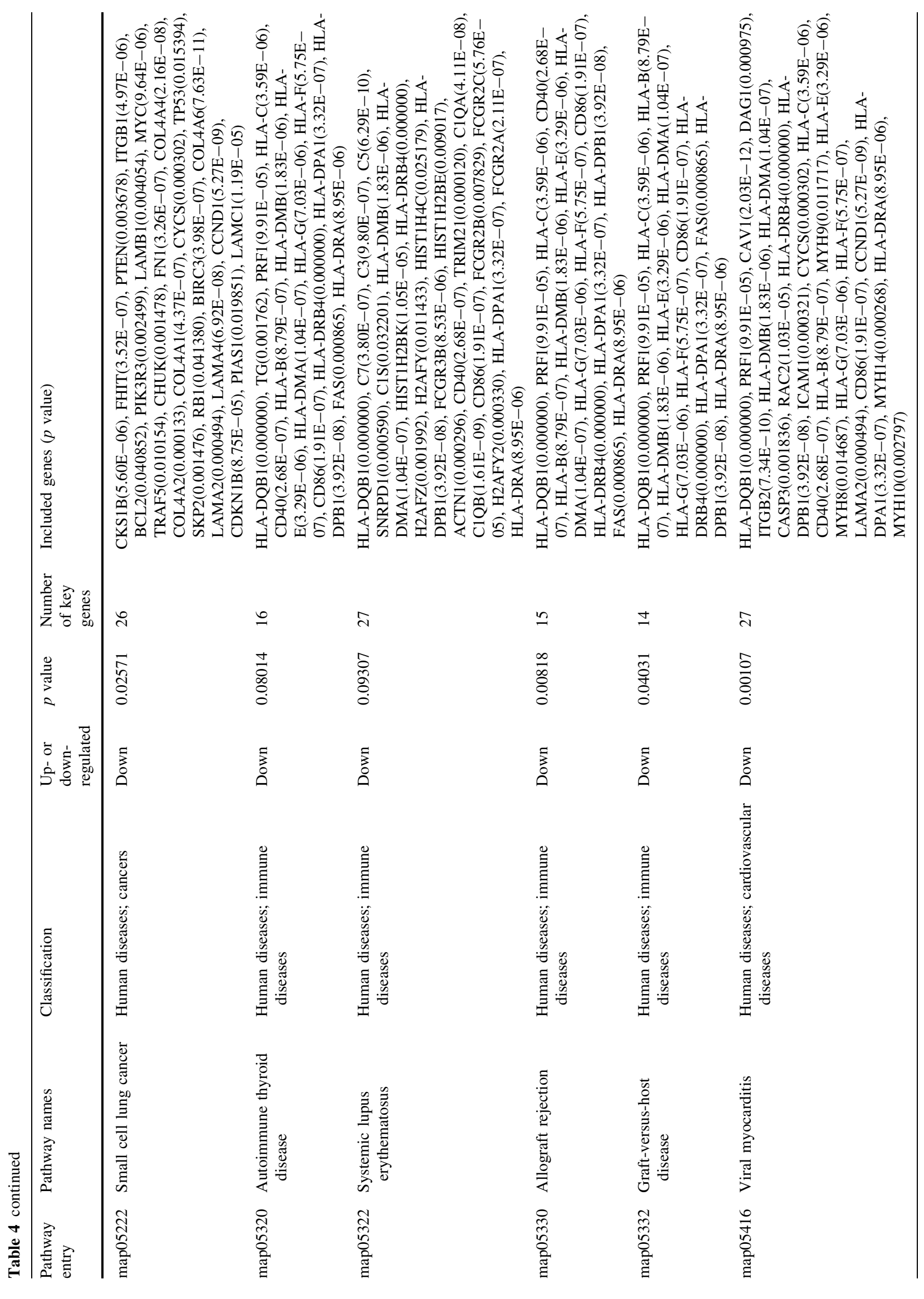


ccRCC is increasingly being recognized as a metabolic disease. Numerous studies have shown a significant association between body mass index, obesity and the development of kidney cancer [18]. In a case-control study from Iowa, diets richest in animal and saturated fats, oleic acid and cholesterol were associated with statistically significant increases in RCC (1.9-2.6-fold, depending on the factor) [19]. These metabolic abnormalities provide protection for the tumor but also may provide a source of vulnerability and therapeutic opportunity. Citrate cycle (TCA cycle) discovered in this study belongs to Carbohydrate metabolism; it is part of a metabolic pathway coupled to mitochondrial oxidative phosphorylation that converts nutrients to energy in aerobic cells. Recently, heterozygous germline mutations in fumarate hydratase (FH) or succinate dehydrogenase (SDH) of the TCA cycle have been shown to predispose individuals to tumors [20]. $\mathrm{SDHB} / \mathrm{C} / \mathrm{D}$ is the key gene in the Citrate cycle and oxidative phosphorylation pathway in our article. SDH is one of the seven known kidney cancer genes involved in pathways that respond to metabolic stress and/or nutrient stimulation [21]. Targeting the fundamental metabolic abnormalities in kidney cancer provides a unique opportunity for the development of more effective forms of therapy for this disease. Recently, early-onset renal tumors have been found to develop in individuals with germ line SDHB mutations [22, 23]. In preclinical models, increased succinate has been shown to inhibit HIF prolyl hydroxylase and affect HIF stability [24]. HIF can strengthen the expression of vascular endothelial growth factor (VEGF), glucose transcript factor 1 (GLUT-1) and glycolytic enzyme in the downstream target genes; promote the generation of blood vessels and energy metabolism of cells; and possibly play an important role in the developing progress in the excessive expression of malignant tumor $[25,26]$.

Cellular processes and cell communication

Focal adhesion pathway (Fig. 1) in our result belongs to cellular processes and cell communication. In cell biology, focal adhesions (cell-matrix adhesions or FAs) are specific types of large macromolecular assemblies through which both mechanical force and regulatory signals are transmitted. Cell-matrix adhesions play essential roles in important biological processes including cell motility, cell proliferation, cell differentiation, regulation of gene expression and cell survival [27]. Tumor epithelial and endothelial cells require attachment to the extracellular matrix (ECM) for survival; on loss of adhesion, they undergo anoikis [28, 29]. Quinazoline-based drugs trigger anoikis in renal cancer cells by targeting the focal adhesion survival signaling. This potent antitumor action against human RCC suggests a novel quinazoline-based therapy targeting renal cancer [30]. VEGFA/B/C (marked by red stars in Fig. 1) is significant gene in focal adhesion pathway. The role of VEGF in particular has been explored as a key factor in the pathogenesis of RCC. VEGF functions to increase vascular permeability, induce endothelial cell proliferation and migration, and promote endothelial cell survival [31]. Furthermore, VEGF receptor expression has been observed in RCC cells, suggesting that VEGF may also serve as an autocrine stimulus in RCC [32]. The high VEGF expression in RCC is the direct result of inactivation of the Von Hippel-Lindau tumor suppressor gene (VHL). Data suggest that VHL inactivation occurs in the majority of ccRCC [33]. Therapeutic targeting of VEGF in RCC has strong biologic rationale. Substantial clinical activity has been reported in clinical trials with VEGF-targeting agents [34, 35]. Further investigation is needed to optimally use these agents for maximal clinical benefit.

\section{Environmental information processing}

Extracellular matrix-receptor interaction and cell adhesion molecule (CAM) pathways were in this classification. They are all about signaling molecules and interaction. The extracellular matrix (ECM) consists of a complex mixture of structural and functional macromolecules and serves an important role in tissue and organ morphogenesis and in the maintenance of cell and tissue structure and function [36]. There is close connection between ECM-receptor interaction and focal adhesion pathway, which is also a significant pathway. At the cell-extracellular matrix contact points, specialized structures are formed and termed focal adhesions, where bundles of actin filaments are anchored to transmembrane receptors of the integrin family through a multi-molecular complex of junctional plaque proteins [37]. There is increasing evidence that certain integrins associate with receptor tyrosine kinases (RTKs) to activate signaling pathways that are necessary for tumor invasion and metastasis [38]. Zhou et al. [39] found that multiple canonical cancer-associated signaling pathways including focal adhesion, cell cycle and ECM-receptor interaction were significantly more likely to be disrupted in ccRCC than expected by chance. This is consistent with the results of our study.

CD47 is a key gene in ECM-receptor interaction pathway, which is involved in the increase in intracellular calcium concentration that occurs upon cell adhesion to extracellular matrix. As has been found by other investigators, CD47 over expression may be associated with ferric nitrilotriacetate-induced renal cortical tubular damage and regeneration that lead to a polycystic state, and with tumor progression and metastasis of the induced RCCs [40]. 


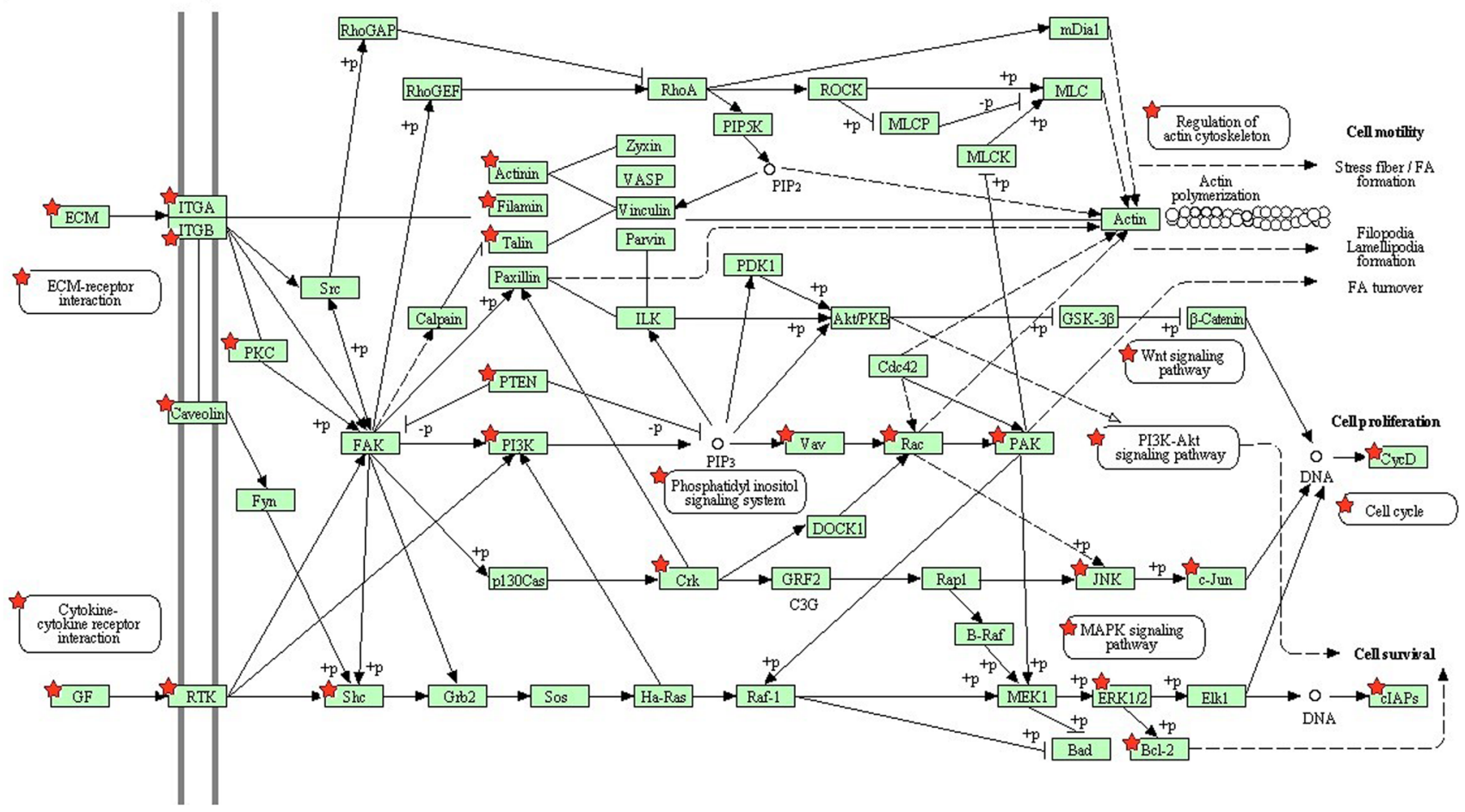

Fig. 1 Focal adhesion pathway (the chart is from the KEGG database, $\star p<0.05$, genes symbolized by $\star$ and correlation $p$ values can be found in map04510 of Table 4)

Other pathways and genes

Human diseases and organismal systems are the two remaining classifications associated with ccRCC. Pathways such as type I diabetes mellitus, epithelial cell signaling in helicobacter pylori infection, bladder cancer, systemic lupus erythematosus and so on all belonged to the classification of human diseases. They are mainly about endocrine and metabolic diseases, neurodegenerative diseases, infectious diseases, cancers, immune diseases and cardiovascular diseases. Some diseases above belong to endocrine or immune system organic system in the classification of organismal systems. Most of genes in these pathways can be enriched in the above pathways. HLA-DQB1 appears in 8 pathways in human diseases, organismal systems and environmental information processing classification is an important gene for ccRCC, and this has widely been reported in the literature. Patients with RCC whose tumors did not express HLA-DQA1 or HLA-DQB1 molecules demonstrated poor clinical response [41]. EGFR and VEGFA/B/C expression in human disease pathways play an important regulatory role in tumor angiogenesis, invasion and metastasis. Based on the EGFR/VEGF target in the treatment of cancer is the hot spot in drug research [42].

\section{Conclusion}

The pathogenesis of ccRCC is quite complicated. It is effective to identify differentially expressed genes and deduce their underlying molecular pathways based on gene set enrichment analysis and meta-analysis. The significant genes and pathways were mainly focused on metabolism, cellular processes and cell communication, environmental information processing, human diseases and organismal systems. They may have some connections with ccRCC. Furthermore, we verified some of the results by searching the literature in the discussion section. The conclusion is relatively reliable and can be used to guide further study. Further experiments are needed to verify specific links between these results and ccRCC.

Conflict of interest The authors declare that they have no conflicts of interests.

Open Access This article is distributed under the terms of the Creative Commons Attribution License which permits any use, distribution, and reproduction in any medium, provided the original author(s) and the source are credited. 


\section{References}

1. Jemal A, Siegel R, Ward E, Murray T, Xu J, Thun MJ (2009) Cancer statistics, 2007. CA Cancer J Clin 57:43-66

2. Cohen HT, McGovern FJ (2005) Renal-cell carcinoma. N Engl J Med 353:2477-2490

3. Rini BI, Rathmell WK, Godley P (2008) Renal cell carcinoma. Curr Opin Oncol 20:300-306

4. Lenburg ME, Liou LS, Gerry NP, Frampton GM, Cohen HT, Christman MF (2003) Previously unidentified changes in renal cell carcinoma gene expression identified by parametric analysis of microarray data. BMC Cancer 3:31

5. Gumz ML, Zou H, Kreinest PA, Childs AC, Belmonte LS, LeGrand SN, Wu KJ, Luxon BA, Sinha M, Parker AS, Sun LZ, Ahlquist DA, Wood CG, Copland JA (2007) Secreted frizzledrelated protein 1 loss contributes to tumor phenotype of clear cell renal cell carcinoma. Clin Cancer Res 13:4740-4749

6. Pena-Llopis S, Vega-Rubin-de-Celis S, Liao A, Leng N, PaviaJimenez A, Wang S, Yamasaki T, Zhrebker L, Sivanand S, Spence P, Kinch L, Hambuch T, Jain S, Lotan Y, Margulis V, Sagalowsky AI, Summerour PB, Kabbani W, Wong SW, Grishin N, Laurent M, Xie XJ, Haudenschild CD, Ross MT, Bentley DR, Kapur P, Brugarolas J (2012) BAP1 loss defines a new class of renal cell carcinoma. Nat Genet 44:751-759

7. Barrett T, Troup DB, Wilhite SE, Ledoux P, Rudnev D, Evangelista C, Kim IF, Soboleva A, Tomashevsky M, Edgar R (2007) NCBI GEO: mining tens of millions of expression profilesdatabase and tools update. Nucleic Acids Res 35:D760-D765

8. Subramanian A, Tamayo P, Mootha VK, Mukherjee S, Ebert BL, Gillette MA, Paulovich A, Pomeroy SL, Golub TR, Lander ES (2005) Gene set enrichment analysis: a knowledge-based approach for interpreting genome-wide expression profiles. Proc Natl Acad Sci USA 102:15545-15550

9. Greenbaum D, Jansen R, Gerstein M (2002) Analysis of mRNA expression and protein abundance data: an approach for the comparison of the enrichment of features in the cellular population of proteins and transcripts. Bioinformatics 18:585-596

10. Hornik K (2012) The comprehensive R archive network. Wiley interdisciplinary reviews: Computational statistics

11. Gregory Alvord W, Roayaei JA, Quiñones OA, Schneider KT (2007) A microarray analysis for differential gene expression in the soybean genome using Bioconductor and R. Brief Bioinform $8(6): 415-431$

12. Gentleman RC, Carey VJ, Bates DM, Bolstad B, Dettling M, Dudoit S, Ellis B, Gautier L, Ge Y, Gentry J (2004) Bioconductor: open software development for computational biology and bioinformatics. Genome Biol 5:R80

13. Ogata H, Goto S, Sato K, Fujibuchi W, Bono H, Kanehisa M (1999) KEGG: kyoto encyclopedia of genes and genomes. Nucleic Acids Res 27:29-34

14. Brown MB (1975) 400: A method for combining non-independent, one-sided tests of significance. Biometrics 987-992

15. MacDonald JW, Ghosh D (2006) COPA-cancer outlier profile analysis. Bioinformatics 22:2950-2951

16. Tun HW, Marlow LA, von Roemeling CA, Cooper SJ, Kreinest P, Wu K, Luxon BA, Sinha M, Anastasiadis PZ, Copland JA (2010) Pathway signature and cellular differentiation in clear cell renal cell carcinoma. PLoS One 5:e10696

17. Maruschke M, Reuter D, Koczan D, Hakenberg OW, Thiesen HJ (2011) Gene expression analysis in clear cell renal cell carcinoma using gene set enrichment analysis for biostatistical management. BJU Int 108:E29-E35

18. Chow WH, Gridley G, Fraumeni JF Jr, Jarvholm B (2000) Obesity, hypertension, and the risk of kidney cancer in men. N Engl J Med 343:1305-1311
19. Brock KE, Gridley G, Chiu BC, Ershow AG, Lynch CF, Cantor KP (2009) Dietary fat and risk of renal cell carcinoma in the USA: a case-control study. Br J Nutr 101:1228

20. Pollard PJ, Wortham NC, Tomlinson IP (2003) The TCA cycle and tumorigenesis: the examples of fumarate hydratase and succinate dehydrogenase. Ann Med 35:632-639

21. Linehan WM, Srinivasan R, Schmidt LS (2010) The genetic basis of kidney cancer: a metabolic disease. Nat Rev Urol 7:277-285

22. Vanharanta S, Buchta M, McWhinney SR, Virta SK, Peczkowska M, Morrison CD, Lehtonen R, Januszewicz A, Jarvinen H, Juhola M, Mecklin JP, Pukkala E, Herva R, Kiuru M, Nupponen NN, Aaltonen LA, Neumann HP, Eng C (2004) Early-onset renal cell carcinoma as a novel extraparaganglial component of SDHBassociated heritable paraganglioma. Am J Hum Genet 74:153-159

23. Ricketts C, Woodward ER, Killick P, Morris MR, Astuti D, Latif F, Maher ER (2008) Germline SDHB mutations and familial renal cell carcinoma. J Natl Cancer Inst 100:1260-1262

24. Isaacs JS, Jung YJ, Mole DR, Lee S, Torres-Cabala C, Chung YL, Merino M, Trepel J, Zbar B, Toro J, Ratcliffe PJ, Linehan WM, Neckers L (2005) HIF overexpression correlates with biallelic loss of fumarate hydratase in renal cancer: novel role of fumarate in regulation of HIF stability. Cancer Cell 8:143-153

25. Carmeliet P, Dor Y, Herbert JM, Fukumura D, Brusselmans K, Dewerchin M, Neeman M, Bono F, Abramovitch R, Maxwell P, Koch CJ, Ratcliffe P, Moons L, Jain RK, Collen D, Keshert E (1998) Role of HIF-1alpha in hypoxia-mediated apoptosis, cell proliferation and tumour angiogenesis. Nature 394:485-490

26. Rapisarda A, Uranchimeg B, Scudiero DA, Selby M, Sausville EA, Shoemaker RH, Melillo G (2002) Identification of small molecule inhibitors of hypoxia-inducible factor 1 transcriptional activation pathway. Cancer Res 62:4316-4324

27. Petit V, Thiery JP (2000) Focal adhesions: structure and dynamics. Biol Cell 92:477-494

28. Frisch SM, Francis H (1994) Disruption of epithelial cell-matrix interactions induces apoptosis. J Cell Biol 124:619-626

29. Frisch SM, Screaton RA (2001) Anoikis mechanisms. Curr Opin Cell Biol 13:555-562

30. Sakamoto S, Schwarze S, Kyprianou N (2011) Anoikis disruption of focal adhesion-Akt signaling impairs renal cell carcinoma. Eur Urol 59:734-744

31. Jacobsen J, Grankvist K, Rasmuson T, Bergh A, Landberg G, Ljungberg B (2004) Expression of vascular endothelial growth factor protein in human renal cell carcinoma. BJU Int 93:297-302

32. Tsuchiya N, Sato K, Akao T, Kakinuma H, Sasaki R, Shimoda N, Satoh S, Habuchi T, Ogawa O, Kato T (2001) Quantitative analysis of gene expressions of vascular endothelial growth factor-related factors and their receptors in renal cell carcinoma. Tohoku J Exp Med 195:101-113

33. Rini BI, Small EJ (2005) Biology and clinical development of vascular endothelial growth factor-targeted therapy in renal cell carcinoma. J Clin Oncol 23:1028-1043

34. Negrier S, Gravis G, Perol D, Chevreau C, Delva R, Bay JO, Blanc E, Ferlay C, Geoffrois L, Rolland F, Legouffe E, Sevin E, Laguerre B, Escudier B (2011) Temsirolimus and bevacizumab, or sunitinib, or interferon alfa and bevacizumab for patients with advanced renal cell carcinoma (TORAVA): a randomised phase 2 trial. Lancet Oncol 12:673-680

35. Rini BI, Escudier B, Tomczak P, Kaprin A, Szczylik C, Hutson TE, Michaelson MD, Gorbunova VA, Gore ME, Rusakov IG, Negrier S, Ou YC, Castellano D, Lim HY, Uemura H, Tarazi J, Cella D, Chen C, Rosbrook B, Kim S, Motzer RJ (2011) Comparative effectiveness of axitinib versus sorafenib in advanced renal cell carcinoma (AXIS): a randomised phase 3 trial. Lancet 378:1931-1939 
36. van der Flier A, Sonnenberg A (2001) Function and interactions of integrins. Cell Tissue Res 305:285-298

37. Burridge K, Fath K, Kelly T, Nuckolls G, Turner C (1988) Focal adhesions: transmembrane junctions between the extracellular matrix and the cytoskeleton. Annu Rev Cell Biol 4:487-525

38. Guo W, Giancotti FG (2004) Integrin signalling during tumour progression. Nat Rev Mol Cell Biol 5:816-826

39. Zhou L, Chen J, Li Z, Li X, Hu X, Huang Y, Zhao X, Liang C, Wang Y, Sun L, Shi M, Xu X, Shen F, Chen M, Han Z, Peng Z, Zhai Q, Zhang Z, Yang R, Ye J, Guan Z, Yang H, Gui Y, Wang J, Cai Z, Zhang X (2010) Integrated profiling of microRNAs and mRNAs: microRNAs located on Xq27.3 associate with clear cell renal cell carcinoma. PLoS One 5:e15224

40. Nishiyama Y, Tanaka T, Naitoh H, Mori C, Fukumoto M, Hiai H, Toyokuni S (1997) Overexpression of integrin-associated protein
(CD47) in rat kidney treated with a renal carcinogen, ferric nitrilotriacetate. Jpn J Cancer Res 88:120-128

41. Mizumori O, Zembutsu H, Kato Y, Tsunoda T, Miya F, Morizono T, Tsukamoto T, Fujioka T, Tomita Y, Kitamura T, Ozono S, Miki T, Naito S, Akaza H, Nakamura Y (2010) Identification of a set of genes associated with response to interleukin-2 and interferonalpha combination therapy for renal cell carcinoma through genome-wide gene expression profiling. Exp Ther Med 1:955-961

42. Dienstmann R, Brana I, Rodon J, Tabernero J (2011) Toxicity as a biomarker of efficacy of molecular targeted therapies: focus on EGFR and VEGF inhibiting anticancer drugs. Oncologist 16:1729-1740 